\title{
矂床的にセメント質剥離が疑われた症例群に対する考察
}

岡野弘幸

\section{Study to the Case Group that Cemental Tear was Doubted Clinically}

Hiroyuki Okano

The cemental tear makes easy bacterial invasion to apical site of the root, and causes collapse of the local and rapid periodontal tissue. This study considered 10 cases of cemental tears detected by our study group.

(1) In all cases, the ages of the patients when the cemental tears were detected were relatively high, with the average of 66.4 years old.

(2) All cases were single root teeth.

(3) Subjects were 8 male and 2 female.

(4) Among the 10 cases, 2 were vital and 8 were nonvital.

(5) Apical cemental tear caused greater loss of periodontal tissue, and cervical cemental tear caused smaller loss of periodontal tissue.

These observations suggest that the causes of cemental tear are associated with traumatic external forces working on teeth and a variety of changes caused by aging of a human being.

Key words : cementum, cemental tear, aging, traumatic occlusion

セメント質剥離は, 根尖方向への細菌の侵入を容易にし, 局所的で急速な歯周組織の崩 壊を引き起こす。今回, 所属スタディグループで見つかったセメント質剥離 10 症例を検 討した。

（1）全症例において患者は比較的高齢であり，その平均年齢は66.4歳であった.

(2) すべて単根歯であった.

（3）性別は，男性8例，女性2例であった。

(4) 10 症例中, 生活歯 2 例, 失活歯 8 例であった.

（5）セメント質剥離が根尖部にあるものは歯周支持組織の峦失が多く，歯頸部にあるも のは歯周支持組織の喪失が少なかった。

以上より，七メント質剥離の原因は，歯牙に対し外傷性に動く外部の力と，ヒトの高齢 化に対応した種々の変化に関係していることが示唆された。 


\section{緒 言}

歯周病は細菌による感染症であり, 正常な歯周組織には, 宿主と細菌との間に微妙な均衡が存在する。そして，宿主 の抵抗力が減少したり, 口腔清掃状態が悪化すると, この 均衡が壊れ，歯周病に罹患する。歯周病は部位特異性を示 す感染症で1)，局所的な悪化は，不良な修復物などの医原 性要因やエナメルプロジェクション, 根面溝などの形態的 要因によるところが多い. 形態的要因は, 先天的なものと 後天的なものに分けられ, 今回報告するセメント質剥離は 後天的なものに属する。このセメント質の剥離は, 根尖方 向への細菌の侵入を容易にし，局所的で急速な歯周組織の 崩壊を引き起こすにもかかわらず，その報告数は非常に少 ない現状にある。

そこで, 今回著者の所属するスタディーグループ内で見 つかったセメント質剥離 10 症例を提示し，その原因と対処 法ならびに疾病の危険性について考察する。

\section{材料と方法}

\section{1. 被験歯}

資料は1995～99 年に著者の所属するスタディーグルー プ会員の診療所に訪れた患者より集められ, 計 10 症例で あった。 セメント質剥離はX線写真（図 1, 2), あるいは 抜歯された歯の検査（図３）で偶然に発見された。

\section{2. セメント質剥離片の病理組織検査}

図1-aは症例 1 (表 1) のX線写真である。上顎右側中

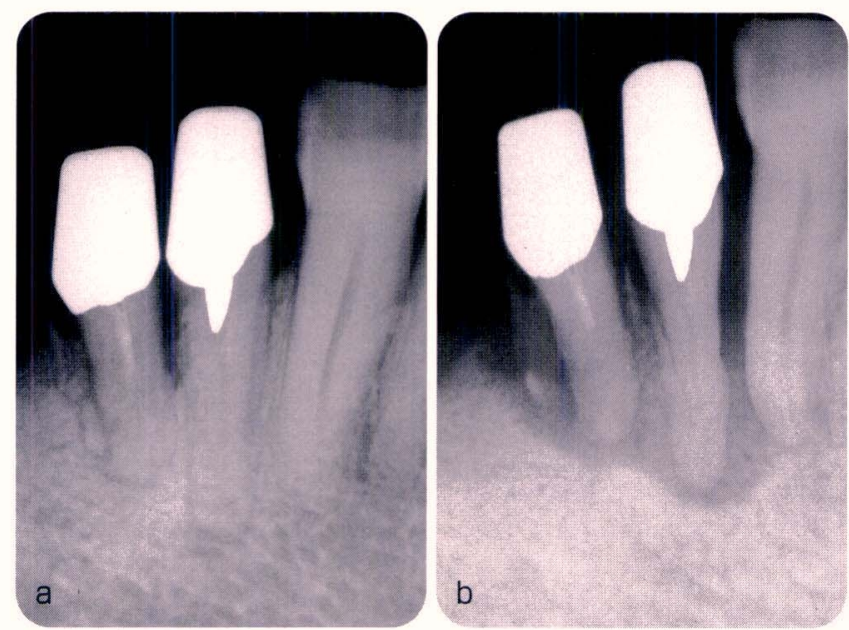

図2 a : 1993年 10月のX線写真. 下顎右側小臼歯部にセメン 卜質剥離が認められる

b : 1995年 12月のX線写真. 下顎右側小臼歯部のセメン 卜質剥離が拡大している
切歯根尖部に帽子状の不透過像が認められたが，この時点 ではその不透過物が何であるかはわからなかった。図 1-b は抜歯後のX線写真であるが，抜歯窩に帽子状の不透過物 が残存している。この帽子状の不透過物が何であるのかを 判断するために, 摘出して病理組織検査をした (図4).

\section{3. 検討内容}

セメント質剥離 10 症例について, 以下の項目について検 討を行った。

（1）セメント質剥離が発見された患者の年齢および性 別.

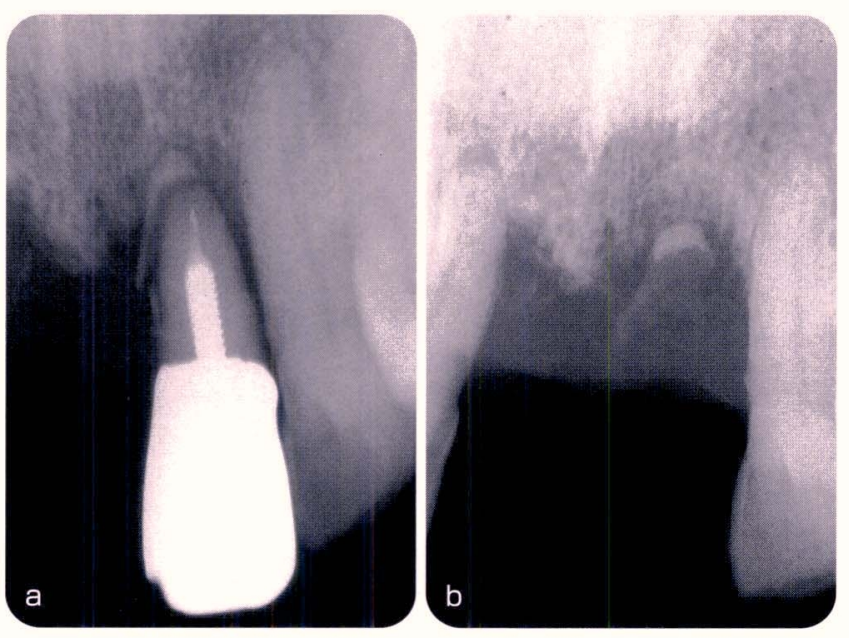

図 $1 a$ ：上顎左側中切歯のX線写真. 根尖部に帽子状の不透過像 が認められる

$\mathrm{b}:$ 上顎左側中切歯抜歯後のX線写真. 抜歯窩根尖部に不透 過像が残存している
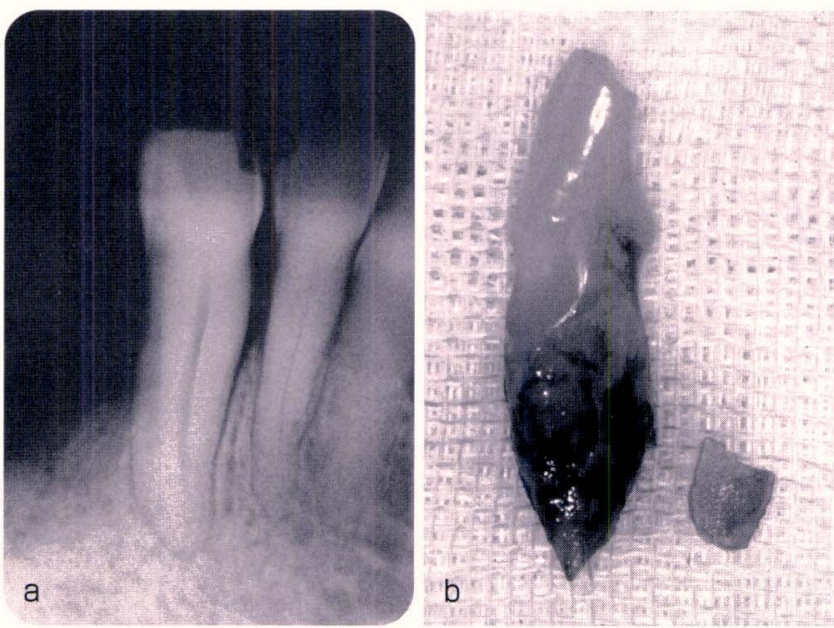

図 3a：1998年 11 月のX線写真. 下顎右側側切歯の唇側面に セメント質剥離が存在しているために，X線写真では剥離 を確認できない

$\mathrm{b}$ : 报歯された歯牙，歯牙にはセメント質が欠落した部分が 認められる 
表 1 セメント質剥離 10 症例の要約

\begin{tabular}{|c|c|c|c|c|c|c|c|}
\hline 症例 & 年齢 & 性別 & 口腔内歯式 & 部 位 & 歯髄の有無 & 歯周支持組織の量 & セメント質剥離が起こった歯牙に加わる外力 \\
\hline \multirow{2}{*}{1} & \multirow{2}{*}{76 歳 } & \multirow{2}{*}{$\sigma^{7}$} & \begin{tabular}{ll|l|l}
432 & $1 \sim 467$ \\
\end{tabular} & \multirow{2}{*}{ 1 （根尖） } & \multirow{2}{*}{ 無 } & \multirow{2}{*}{ 少ない } & \multirow{2}{*}{ 歯周病による臼歯部咬合の減少 } \\
\hline & & & \begin{tabular}{l|l|l|}
$6 \sim 2$ & $2 \sim 6$ \\
\end{tabular} & & & & \\
\hline \multirow{2}{*}{2} & \multirow{2}{*}{56 歳 } & \multirow{2}{*}{ 우 } & $7653 \sim 24 \sim 7$ & \multirow{2}{*}{1 (近心) } & \multirow{2}{*}{ 無 } & \multirow{2}{*}{ 多い } & \multirow{2}{*}{ 切端咬合 } \\
\hline & & & $7653 \sim 467$ & & & & \\
\hline \multirow{2}{*}{3} & \multirow{2}{*}{64 歳 } & \multirow{2}{*}{ 우 } & \begin{tabular}{l|l}
3 \\
\end{tabular} & \multirow{2}{*}{ 运（根尖） } & \multirow{2}{*}{ 無 } & \multirow{2}{*}{ 少ない } & \multirow{2}{*}{ パーシャルデンチャーの支台歯（○リング） } \\
\hline & & & $764 \sim 4$ & & & & \\
\hline 4 & 70 歳 & $0^{7}$ & 2 & $\sqrt{4}$ (近心) & 無 & 多い & パーシャルデンチャーの支台歯（○リング） \\
\hline \multirow{3}{*}{5} & \multirow{3}{*}{68 歳 } & \multirow{3}{*}{$\sigma^{7}$} & & \multirow{3}{*}{$\Gamma$ (根尖) } & \multirow{3}{*}{ 有 } & \multirow{3}{*}{ 少ない } & \multirow{3}{*}{ 歯周病による臼歯部咬合の減少 } \\
\hline & & & $7-58$ & & & & \\
\hline & & & $4 \uparrow 6$ & & & & \\
\hline 6 & 50 撋 & $\pi$ & $653+57$ & 1」(洁心) & 無 & 多仿 & 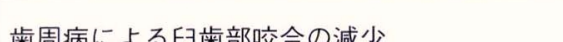 \\
\hline 6 & 59 戚 & o' & $7+7$ & $1\left(2, \mathbb{R}^{2}\right)$ & 璦 & 36 & 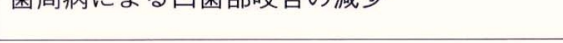 \\
\hline & & $\pi$ & $74 \sim 1 \mid 246$ & 4. (㝨心) & 無 & 多人到 & パーシャ゙デンチャーの古台歯（ユーヌス冠） \\
\hline 7 & ７1戚 & $\sigma^{1}$ & \begin{tabular}{l|l}
$5 \sim 13 \sim 68$
\end{tabular} & $4 \mid($ 退心) & 無 & 多い & 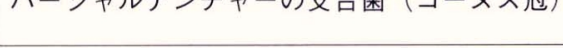 \\
\hline 8 & 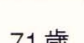 & $\pi$ & $74 \sim 1 \mid 246$ & 5 (猿门) & 無 & 多方 & パージャデンチャーの支台歲（コーヌス冠） \\
\hline 0 & 月1标 & $\sigma^{\circ}$ & $5 \sim 1 \mid 13 \sim 68$ & 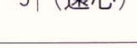 & 点 & 30 & 年 \\
\hline 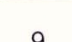 & 74歲 & $\pi$ & $74 \sim 1 \mid 246$ & 2 (辰側) & 有 & 多h1 & 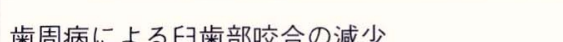 \\
\hline 9 & /4戚 & $\sigma^{\prime \prime}$ & \begin{tabular}{l|l}
$3 \sim 13 \sim 68$
\end{tabular} & 2|(答則) & 有 & 多、 & 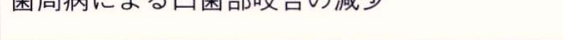 \\
\hline 10 & 55歲 & $\pi$ & \begin{tabular}{l|l}
$7 \sim 2$ & $2 \sim 7$
\end{tabular} & 5 （猿门） & 無 & 名い & ブリッジの支台歯 \\
\hline 10 & Jad & & $75 \uparrow 57$ & F & (in & (2) & 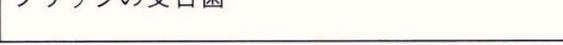 \\
\hline
\end{tabular}

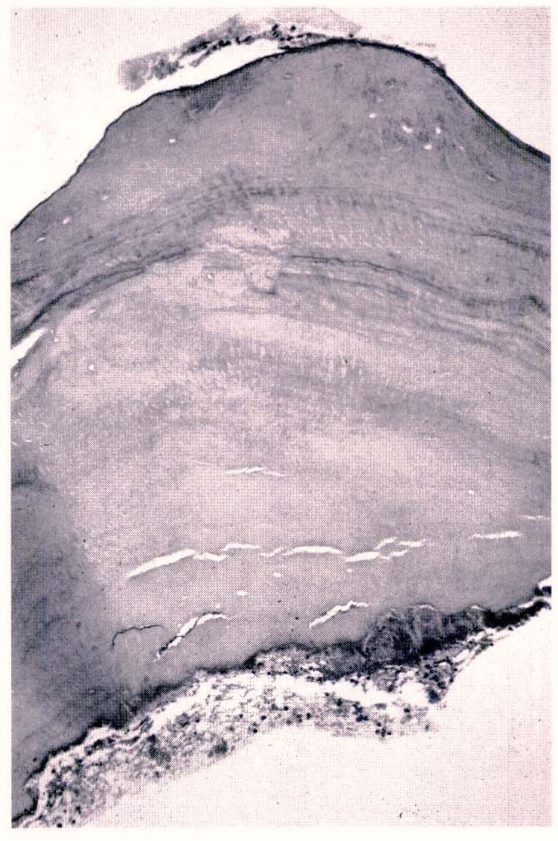

図4摘出した歯牙様 硬組織の病理組 織標本. 剥離面 には多量の細菌 塊が認められる

（2）セメント質剥離の起こった部位.

（3）セメント質剥離が起こった歯牙の歯髄の有無および 歯周支持組織の量.

（4）セメント質剥離が起こった歯牙に加わる外力につい $\tau$.

\section{結 果}

\section{1. 病理組織所見}

硬組織は，封入細胞にそしく，層板構造を示すセメント 質で，小腔内の細胞は消失して腐骨の状態となっており， 歯根に対応すると思わ机る部分には表面に多量の細菌塊の 付着を認める。検体の結合組織側には若干の骨様硬組織や 鬆粗な繊維性結合組織を認め, これらは残存した歯根膜組 織である可能性も考えられる。

以上の所見から, 上顎右側中切歯根尖部にあった帽子状 の不透過像は, セメント質が剥離し細菌に感染したもので あることが明らかになった。

\section{2. セメント質剥離 10 症例の傾向}

表 1 に所属スタディーグループ内で認められたセメン 卜質剥離 10 症例をまとめた。

（1）全症例において患者は比較的高齡であり，その平均 年齢は66.4歳であった.

（2）すべて単根歯であった.

（3）性別は，男性8例，女性2例であった。

（4）10症例中，生活歯2例，失活歯8例であった.

（5）セメント質剥離が根尖部にあるものは歯周支持組織 の㳖失が多く, 歯頸部にあるものは歯周支持組織の弈 失が少なかった。 


\section{考 察}

\section{1. セメント質剥離 10 症例の傾向から}

\section{1）好発年齢}

歯頸部のセメント質剥離の原因の一つとして, 加齢変化 の関与が報告されている ${ }^{2}$. 今回提示した 10 症例の平均年 齢が66.4歳であることから，セメント質剥離は高齢者に多 発しやすいという点で，この報告と一致していた。

\section{2）好発部位}

今回提示した 10 症例すべてが単根歯であった. 過去の文 献でも, セメント質剥離は単根歯の報告が多いが2, 3), 下顎 左側第一大臼歯の症例も報告されており ${ }^{2}$, 単根歯固有の ものではない. しかし, 圧倒的に単根歯の症例が多い原因 には，単根歯に生じやすいメカニズムがある可能性が考え られるが, 現在よくわかっていない. 複根歯に生じたセメ ント質剥離がX線写真で見つけにくいことも単根歯の症例 が多い理由と考えられる。

$\mathrm{X}$ 線写真はX $\mathrm{X}$ 線の透過性の差を使い, 三次元の被写体を 二次元の像として表示する. 頬舌的幅の厚い部位や, 複根 歯のように重なる情報が多い部位では読影が難しくなる. また, 煩・舌側面に生じた剥離は, 近遠心的に走る歯牙の 縦破折同様, $\mathrm{X}$ 線では発見できない. 以上のような X線写 真の性質により発見されないセメント質剥離も多く存在す るであろう。

\section{3）口腔内所見}

今回提示した 10 症例の口腔内所見をみると, セメント質 剥離は欠損補経の支台歯あるいは歯周病に伴う臼歯部咬合 支持の減少した前歯に生じている。これは，臼歯部咬合支 持の減少による前歯部咬合力の増加, 欠損補綴の支台歯と なったことによる機能圧の増加が，歯牙に対する外傷力と して働いた結果であり, Glickmanの報告(4) と同様に歯が激 しい外部の力にさらされるとセメント質が剥離するといえ る.

\section{4）性 差}

女性よりも男性に多発する傾向が認められた。この傾向 は, 一般的に女性よりも男性の咬合力が大きく, その力が 外傷として働き，セメント質が剥離したと考えられる。

\section{5）歯髄の有無}

今回提示した 10 症例中, 生活歯 2 例, 失活歯 8 例であっ た。このことは, 歯髄の失活による歯質の変化, 根管内ポ ストによる歯牙への応力の変化が関与していると考えられ る.

セメント質は歯根膜から, 象牙質は歯髄から栄養供給を 受けている.セメント質は歯髄の有無に影響を受けないが,
象牙質は歯髄が失活すると栄養供給を断たれ，コラーゲン などの有機質に変化が生じ弾性が減少する。この変化は, 象牙質とセメント質の力に対する変形量の調和を乱し, 七 メントー象牙境に加わる応力を変化させると考えられる.

失活歯では, 歯冠部歯質の崩壊により, 根管内に維持を 求めた支台築造が施される。根管内ポストが装着されると, 外力はポストを介して歯牙に内側性に加えられる ${ }^{5)}$. 根管 内ポストの長さおよび形態により, 歯根に加わる応力が変 化する ${ }^{6}$. 根管内ポストの存在が歯牙への応力を変化させ る.

このような歯牙に加わる応力の変化が, セメント質の剥 離する条件をつくりだすと思われる。

\section{2. セメント質剥離のメカニズムと老化}

以下に, 高齢化に伴う歯質の変化, 外傷に対する応答の 変化について考察する.

\section{1）セメント質剥離と加齢変化}

セメント質は, 歯根形成や歯の萌出に伴って形成される 無細胞セメント質と, 歯の萌出後抢よび機能的な要求に対 する反応として形成される有細胞セメント質に分類され， セメント質の厚さは一生を通じて増加する”.

高齢者の歯根中央部に生じたセメント質の剥離片の厚み を計測したところ $512 \mu \mathrm{m}$ であり ${ }^{3)}$ ，成人の同部位における 平均的セメント質の厚さ, 近心 $135 \mu \mathrm{m}$, 遠心 $\left.216 \mu \mathrm{m}^{7}\right)$ と比 較すると，かなり肥大していることがわかる.

また, 歯根膜の加齢変化は, 固有歯槽骨外側の外基礎層 板が吸収することにより，歯根膜線維の断裂や減少が起こ $3^{8)}$. この歯根膜の変化は咬合力に対する緩衝能力を低下 させ, 歯牙への直接のダメージを増加させるといえる.

\section{2）セメント質剥離の分類}

剥離が生じた場所から，セメント質剥離は 2 つに分類さ れる。根尖部に扔ける帽子状の剥離と, 歯頸部に扔ける棘 状の剥離である。 セメント質剥離の生じた場所と歯周支持 組織の量には関係がある。すすなわち, 歯周支持組織の丧失 が多い歯牙では，歯牙にかかる力はすべて根尖部付近に加 えられる.根尖部では特にセメント質の肥大は顕著であり， このような状態の歯牙に外傷力が㗢くと根尖部で帽子状の セメント質剥離が生じると考えられる.

歯周支持組織の喪失が少ない歯牙では動摇が少ないため に, 外傷力が働くと歯槽骨骨頂部に応力が集中して歯牙は しなる，歯頸部における棘状のセメント質剥離は，力によ る歯牙のしなりと, 加齢変化によるセメント質の肥大およ び弾性の低下, 歯根膜の加齢変化に伴う力に対する緩衝作 用の減少が関係していると考えられる. 


\section{3）剥離後のセメント質の修復}

新生セメント質による，セメント質剥離片の修復の可能 性についての報告がある4,9)。このことから考えると，七 メント質の損傷は頻繁に起こっているが，その損傷は修復 され発見されていない可能性もある。しかし，ヒトの加齢 変化は剥がれたセメント質の修復能力を減少させる。 そし て，そこに細菌が侵入することにより急速な歯周病を引き 起こす。その結果, セメント質剥離として高齢者に多く発 見されているとも考えられる.

\section{4）セメント質剥離の難治性}

10 症例のうち 8 症例までが抜歯に至っている事実は，そ の治療の困難性を説明している，セメント質剥離は，この ような重篤な歯周病を引き起こす。しかし, 剥離片を除去 することにより最悪の事態を免れた症例もあり，早期発見 が重要となる．高齢者のX線診査では注意しなければいけ ない項目の一つである.

\section{まとめ}

病理組織検査から，剥離面に沿って細菌が多量に認めら れており，セメント質剥離は歯周病の進行に大きな影響を 与える疾病である.

今回の調査より，セメント質はヒトの加齢変化と外傷性 の力の影響により剥離することが判明した．ヒトの加齢変 化に関して歯科医師は関与できないが，咬合により歯牙に 加わる力に関してならば関与することはできる，外傷性咬 合を与えないことがセメント質剥離を予防するうえで重要 であり, 支台歯負担軽減を考慮したパーシャルデンチャー の設計やブラキシズムなどに対するカのコントロールは考
慮する必要がある。

稿を終えるにあたり，ご指導，ご校閲を賜った調布市開 業・阿部二郎先生に対し深く謝意を表します。

\section{参考文献}

1）Lindhe, J. 著; 岡本 浩 監訳：臨床歯周病学. 第 2 版： 30-33，131-136，医歯薬出版（東京）, 1986.

2) Ishikawa, I., Oda, S., Hayashi, J., Arakawa, S. : Cervical cemental tears in older patients with adult periodontitis. Case reports. J. Periodontol., 67 : 15-20, 1996.

3) Kunt, N.L., Tryggve, L., Kunt, A.S. : Cemental tear : A risk factor in periodontal attachment loss. J. Periodontol., 67 : 583588, 1996.

4) Carranza, F.A. : Glickman's Clinical Periodontology. 7th ed. : 60-61, The W.B. Saunders Co. (Philadelphia), 1990.

5）真鍋 顕：3本の柱歯髄の保存・ポストの見直し・コー ピングテクニック．補綴臨床, 30 : 73-81, 1997.

6) 鵜山秀夫：支台築造に関する力学的研究. 鶴見菌学, 7 : 79-98, 1981.

7) Dastmalchi, R., et al. : Cementum thickness and mesial drift. J. Clin. Periodontol., 17 : 709-713, 1990.

8）浦郷篤史：口腔諸組織の加齢変化. 第 1 版：61-114, ク インテッセンス出版（東京), 1991.

9) Moskow, B.S. : Calculus attachment in cemental separations. J. Periodontol., 40 : 125-130, 1969.

別刷請求先：岡野弘幸 